\title{
Quaternary observations in southern Peary Land, North Greenland
}

\section{Anker Weidick}

A geological group consisting of the author and P. R. Dawes accompanied the 1975 Greenland Ice Sheet Programme's (GISP) ice drilling operation at Hans Tavsens Iskappe, south-western Peary Land. The primary objective of the group was to investigate the Quaternary history of the area south of the ice cap as a supplement to the work done elsewhere in Peary Land by the various Peary Land Expeditions (Troelsen, 1952; Kirkeby, 1963: Fredskild, 1969), Operations Groundhog and Lead Dog (Stoertz \& Needleman, 1957; Davies, 1972; Ahnert, 1960) and the British Joint Services Expedition (Dawes, 1970).

A stay at Kap Harald Moltke was used to map moraines, kame terraces, marine terraces and fluviatile deposits in the area between Kølen, Børglum Elv and Trehøje Halvø. Samples of driftwood at 11-12 and 13-14 m above sea level and of shells at 2-5, 12, 17 and 45-50 m above sea level were collected for radiocarbon dating in order to supplement earlier datings in the area. Earlier investigations (e.g. Christie, 1975) have indicated that the Inland Ice formerly extended far north in the Børglum Elv area and that this phase was followed by a subsequent expansion of local ice caps in the north through Børglum Elv to Jørgen Brønlund Fjord.

Flights through Wandel Dal between Jørgen Brønlund Fjord and Adams Gletscher as well as studies of aerial photographs, suggest that moraine lobes south of $\emptyset$ vre Midsommers $\varnothing$ and Nedre Midsommers $\varnothing$ could originate from a source area in the north. If so, it is to be expected that the young advance towards the south was caused by a merging of Hans Tavsens Iskappe with others further east at least to Børglum Elv to form the so-called 'north cap'. This part of Peary Land is characterised by a prominent plateau landscape. The plateau surfaces are situated just below the present glaciation limit and therefore it would only be necessary to lower this limit by $200-300 \mathrm{~m}$ to form an ice cover with such 'north cap' dimensions.

Around Kap Harald Moltke area there is a marked contrast between badly defined terrace levels between $70 \pm 10$ and $.125 \mathrm{~m}$ above sea level and lower and younger well defined systems of terraces, beach ridges and deltas. The investigations around Kap Harald Moltke substantiate the idea that the outer margins of the 'north cap' were connected with the initiation of the younger system of beach lines which according to the present radiocarbon dates of the area indicate an age of about 8000 years B. P. This age is at present therefore the best guess of the beginning of the recession of the 'north cap'. The older higher systems of terraces might be connected with the uplift after the recession of the southern Inland Ice at an earlier stage but the age of this is unknown.

In connection with the ice drilling in the firn of the Hans Tavsens Iskappe the geological group had an opportunity to be transported to a camp site at the east side of Adams Gletscher near its terminus (fig. 4). Occurrence of erratics of granite, gneiss and other crystalline rocks up to the top of the plateau (approximately $850 \mathrm{~m}$ above sea level) revealed that the Inland Ice from the south once covered the whole region. This is in agreement with a former extent of the Inland Ice at the mouth of J. P. Koch Fjord as plotted earlier by Koch (1928). The 
bedrock investigations of Dawes (this report) revealed that important block faults project the Eocambrian succession much farther northwards than hitherto known, to reach J. P. Koch Fjord and the southern part of Hans Tavsens Iskappe. This should be borne in mind in any interpretation of the distribution of erratic sedimentary blocks.

Younger marginal moraines all revealed that the dominant feature is an expansion from the south and not from any local ice cap in the east. Near the glacier front kame terraces occurred at 70 and $80 \mathrm{~m}$ above sea level. However, all terraces above $40-50 \mathrm{~m}$ above sea level are indistinct. Around $40 \mathrm{~m}$ above sea level a main silt terrace dominates the interior of a valley close to its front and numerous wave cut terraces occur below this altitude.

It is unknown whether the lower terrace systems are of marine origin or due to ice damming of the valley of Adams Gletscher. The occurrence of shell fragments in the neoglacial moraines around Adams Gletscher supports the first possibility.

The neoglacial moraines indicate a lowering of the surface of Adams Gletscher. The lowering has been 3-10 m at Aftenstjernes $\varnothing$ (glacier surface at $370 \mathrm{~m}$ above sea level), at the camp site $20 \mathrm{~m}$ (glacier surface $70-90 \mathrm{~m}$ above sea level) and at the front $80 \mathrm{~m}$ as minimum. A $10 \mathrm{~m}$ shore line in the valley at the glacier front indicates an ice damming during the neoglacial advance. Aerial photographs from 1953 and 1961 reveal a continuous but slight thinning of the front up to the present time.

\section{Acknowledgements}

The field work was made possibly by the Danish military operation 'Brilliant Ice'. Transport between Thule Air Base and Peary Land was supplied by Royal Danish Air Force C-54 and C-130 aircraft and a Grønlandsfly S-61 helicopter lifted the 2-man geological group from the natural airstrip at Kap Moltke, Jørgen Brønlund Fjord, into the field camp on the east side of Adams Gletscher. Sirius Patrol personnel provided generous hospitality during the stay at Kap Moltke.

\section{References}

Ahnert, F. 1960: The accessibility and traversability of southern Peary Land, North Greenland. In: Report of environmental operation Lead Dog 1960. U.S. Army Transportation Board TCB-60-023-EO, 102-133.

Christie, R. L. 1975: Glacial features of the Børglum Elv region, eastern North Greenland. Rapp. Grønlands geol. Unders. 75, 26-28.

Dawes, P. R. 1970: Quaternary studies in northern Peary Land. Rapp. Grønlands geol. Unders. 28, 15-16.

Davies, W. E. 1972: Landscape of Northern Greenland. Spec. Rep. Cold Reg. Res. Engng. Lab. 164, 70 pp.

Fredskild, B. 1969: A postglacial standard pollendiagram from Peary Land, North Greenland, Pollen Spores 11, 573-583.

Kirkeby, P. 1963: Rapport over det kvartærgeologiske feltarbejde udført på den 2. Peary Land Ekspedition sommeren 1963. Grønlands geol. Unders. internal report, $21 \mathrm{pp}$.

Koch, L. 1928: The physiography of North Greenland. In: Vahl, M. et al. (edit.) Greenland 1, 491-518. Copenhagen \& London: Reitzel \& Oxford U. P.

Stoertz, G. E. \& Needleman, S. M. 1957: Report on Operation Groundhog North Greenland, 1957. Investigation of ice-free sites for aircraft landings in northern and eastern Greenland and results of test 
landing of C-124 at Brønlunds Fjord, North Greenland. Rep. Air Force Cambridge Research Center, $38 \mathrm{pp}$.

Troelsen, J. 1952: Notes on the Pleistocene geology of Peary Land, North Greenland. Meddr Dansk geol. Foren. 12, 211-220.

\title{
Cambrian - Early Ordovician stratigraphy in south-western Washington Land, western North Greenland
}

\author{
Niels Henriksen and John S. Peel
}

Geological reconnaissance undertaken in recent years by Dawes $(1971 ; 1975)$, and Peel \& Christie (1975) in preparation for a major mapping project in North Greenland continued in 1975 with a six week season in south-western Washington Land (fig. 5). The aim was to establish a reference profile through the lowermost Palaeozoic sequence between Cass Fjord and Humboldt Gletscher, and to obtain a preliminary idea of the possibilities for geological mapping of the platform terrain.

The Lower Palaeozoic stratigraphy of southern Washington Land has previously been studied by Koch (1929) and Troelsen (1950) who reported a sequence of dolomites and limestones of Eocambrian to Silurian age. The recognition of the Eocambrian and Cambrian deposits was based on a loose correlation with occurrences in Inglefield Land, without confirmatory fossil evidence. However, the division of Ordovician and Silurian deposits was largely proposed in Washington Land.

During our field work a composite section of the lowest $c .900 \mathrm{~m}$ of the sequence exposed in south-western Washington Land was established on the basis of 10 stratigraphical sections. The earlier results of Koch (1929) and Troelsen (1950) were partly confirmed, but in addition faunal evidence for the existence of Middle and Upper Cambrian strata was found. The Cass Fjord Formation is revised to include some of those strata and three new formations are established informally (fig. 6). Of these the Kastrup Elv and Telt Bugt formations are proposed for strata below the Cass Fjord Formation, which were only briefly noted by Koch (1929). The Christian Elv formation is proposed for strata between the Cape Clay and Poulsen Cliff Formations, the boundary between these two later formations not having been observed by Troelsen (1950).

Apart from the lowest $c .140 \mathrm{~m}$ of dolomites, the sequence is formed by various types of limestones with intercalations of dolomite, siltstone and shale, and occasional beds of sandstone and anhydrite. The sequence reflects shallow water shelf deposition; no major unconformities have been found. Fossils were collected throughout the limestone sequence and indicate deposition through the middle and late Cambrian into the early Ordovician.

The rocks were examined in two areas; one immediately north of Humboldt Gletscher, east of Benton Bugt, and the other east of the head of Cass Fjord (fig. 5). In both areas the rocks are flat lying, seldom dipping more than a few degrees. The youngest part of the section is confined to the northernmost part of the two visited areas as a result of the general 